\title{
STAROŚĆ W BIBLII
}

W rozmowie z ludźmi starszymi bardzo często można usłyszeć takie stwierdzenie: „Bogu nie udała się starość". Doświadczenie ludzkie od najdawniejszych czasów pokazuje starość jako coś negatywnego. Nawet najstarsze teksty pisane, odnoszące się do ostatniego etapu życia, mówią o nim bardzo negatywnie. Wysoki urzędnik faraona, Ptah-hetep, żyjący około 2450 lat przed Chrystusem, napisał tak:

O Władco, mój Panie! Oto przybywa już starość, przychodzą podeszłe lata, nadciąga czas słabości i zawodzi głowa. Serce pracuje ospale, oczy słabną, uszy nie słyszą, sił jest coraz mniej z powodu słabego serca, a usta milkną i nie mogą mówić. Serce zaczyna zapominać i nie może już sobie przypomnieć wczorajszego dnia, kości zaś cierpią ze starości. Brakuje smaku, a wszystko, czym obdarzają człowieka sędziwe lata, jest złe ${ }^{1}$.

1 Cyt. za: P. Ostański, Historiozbawcza wizja starości w Piśmie Świętym. Studium egzegetyczno-teologiczne, Poznań 2007, s. 159. 
Jak to jest faktycznie? Czy starość zawsze wiąże się tylko z trudem i cierpieniem? Czy musi być doświadczeniem negatywnym? Czy można jakoś przygotować się do tego etapu życia? Co Biblia mówi o starości? Jak ocenia ludzi w podeszłym wieku? Odpowiedź na te pytania jest zasadniczym celem niniejszego artykułu.

\section{1. \\ Czy Adam i Ewa mieli być wiecznie młodzi?}

Tak postawione pytanie brzmi prowokacyjnie. Jednak dokumenty Kościoła zdają się nauczać w tym właśnie duchu. W Katechizmie Kościoła katolickiego czytamy: „Dopóki człowiek pozostawał w zażyłości z Bogiem, nie miał ani umierać, ani cierpieć" (KKK nr 376). Zażyłość człowieka z Bogiem rozumiana jest w tej wypowiedzi Kościoła jako stan harmonii, w której człowiek pozostawał z Bogiem, zanim popełnił grzech pierworodny. Jednak wnikliwa egzegeza wcale nie musi prowadzić do takiego wniosku, że człowiek stworzony przez Boga, zanim popełnił grzech, miał być wiecznie młody i miał nie umierać ani też nie cierpieć.

Warto zwrócić uwagę na kolejne wypowiedzi wzięte z Tradycji Kościoła. Sobór Trydencki wyraźnie orzekał, że śmierć weszła na świat z powodu grzechu człowieka (por. Sobór Trydencki, DS 1511). 
Wypowiedź ta suponuje, że Bóg stworzył człowieka do życia i nie chciał, aby człowiek umierał. $Z$ tego toku myślenia wynika, że przez grzech człowiek „zepsuł” dzieło Boże. Sobór Watykański II w Konstytucji duszpasterskiej o Kościele w świecie współczesnym Gaudium et spes idzie jeszcze krok dalej. „Śmierć cielesna, od której człowiek byłby wolny, gdyby nie zgrzeszył, jest ostatnim wrogiem człowieka, który musi zostać zwyciężony" (KDK 18).

Pytanie postawione powyżej można sformułować nieco inaczej, tak jak to uczynił ks. prof. Waldemar Chrostowski: Czy Adam i Ewa mieli się nie starzeć i nie umierać? ${ }^{2}$ Analizy przeprowadzone przez ks. Chrostowskiego jednoznacznie prowadzą do wniosku, że w Bożym zamyśle człowiek żyje na ziemi tylko przez pewien czas i, tak jak cały świat stworzony przez Boga, również i on poddany jest przemijaniu. Tak jak rośliny zasiane w ziemię kiełkują, wyrastają, często pięknie kwitną, wydają owoce, a w końcu obumierają, podobnie i człowiek poczyna się pod sercem matki, rozwija w jej łonie, przychodzi na świat, rośnie, przeżywa okres młodości,

2 Por. W. Chrostowski, Czy Adam i Ewa mieli się nie starzeć i nie umierać? Egzegetyczny przyczynek do nauczania o nieśmiertelności pierwszych ludzi, [w:] „Verbum caro factum est”. Księga pamiątkowa dla Księdza Profesora Tomasza Jelonka w 70. rocznicę urodzin, red. R. Bogacz, W. Chrostowski, Warszawa 2007, s. 151-179. 
wreszcie dochodzi do pełni życia, po której zaczyna się czas starzenia, często połączony z bólem, chorobą, w końcu nadchodzi śmierć. Jednak w tym kontekście jawi się pytanie: jak rozumieć śmierć? Czy jest ona końcem wszystkiego? Co na ten temat mówią teksty objawione? Na te pytania postaramy się dać odpowiedź przy końcu niniejszego artykułu.

\section{1 . \\ Problem długowieczności}

W okresie prehistorii, przed potopem, ludzie mieli żyć znacznie dłużej niż dziś. Księga Rodzaju podaje wiek niektórych osób, zbliżony do tysiąca. Według Biblii Adam osiągnął wiek 930 lat, Set żył 912 lat, Enosz 905 lat, Jared 962 lata (Rdz 5, 1-32). Najwyższy wiek spośród wymienionych $\mathrm{w}$ tym rozdziale patriarchów osiągnął Metuszelach - 969 lat. Czy rzeczywiście ludzie osiągali wtedy taki wiek? Wydaje się to mało prawdopodobne. Poza teoretycznym rozważaniem nie ma żadnych sposobów, aby sprawdzić wiarygodność tego przekazu. Niektórzy bibliści próbują porównywać tę długowieczność Setytów ze starożytną listą królów sumeryjskich. Taką listę zapisał w transkrypcji greckiej Beressos w III wieku przed Chrystusem. Lista ta podaje wiek panowania władców sięgający nawet 64800 lat. Bardziej zbliżona do danych z Rdz 5, 1-32 jest tablica z Filadelfii, która przedstawia 
długość rządów władców babilońskich sprawujących władzę przed potopem ${ }^{3}$. W czasach prehistorycznych długowieczność była rozumiana jako znak Bożego błogosławieństwa. Wówczas jeszcze nie było Bożego objawienia dotyczącego życia po śmierci. Dlatego jedynym znakiem miłości Boga do człowieka było jego powodzenie, bogactwo, zdrowie i długie życie.

Brak wiary $\mathrm{w}$ życie wieczne widoczny jest $\mathrm{w}$ Ps 88 (87), 11-13. Psalmista znajdujący się w ciężkim położeniu stawia Bogu pytania: „Czy możesz zdziałać cud dla umarłych? Czy mogą powstać cienie, aby Cię chwalić? Czy rozprawia się w grobie o Twej łaskawości albo o wierności Twej - w miejscu zniszczenia? Czy można rozpoznać Twe cuda w ciemnościach, a sprawiedliwość Twoją - w miejscu zapomnienia?”. W pytaniach tych można dostrzec wpływy z Ugarit. Kraina cieni była rozumiana jako miejsce zguby, śmierci. Stamtąd nie może wydobyć się żaden głos uwielbienia Boga. Jedynie Bóg mógłby uczynić cud i wskrzesić człowieka, ale czy zechce to uczynić? ${ }^{4}$

3 Według danych z tablicy z Filadelfii poszczególni władcy babilońscy rządzili: Galumum - 900 lat; Zugagib - 840 lat; Aripi - 720 lat; Etana 635 lat; Pilikam - 350 lat; Enmennunna - 611 lat; Melakisz - 900 lat; Barsalnunna - 1200 lat. Por. G. Barton, Old age (Semitic and Egyptian), [w:] Encyclopaedia of religion and ethics, ed. by J. Hastinfs, vol. 9, New York 1960, s. $478-479$.

4 Por. S. Łach, Księga Psalmów. Wstęp - przekład z oryginału, komentarz - ekskursy, Pallotinum, Poznań 1990, s. 388. 


\section{2 .}

Szacunek dla starszych rodziców

Biblia ukazuje człowieka starszego jako tego, kto dzięki doświadczeniu nabył mądrość życia. Niestety ta mądrość nie przychodzi automatycznie, wraz z wiekiem. Może ją osiągnąć jedynie ten człowiek, który potrafi wyciągać wnioski ze swego doświadczenia. Ważną rzeczą jest też konfrontowanie tych wniosków z Bogiem. Stąd w Ps 90(89), 12 można znaleźć modlitwę: „Naucz nas liczyć dni nasze, abyśmy osiągnęli mądrość serca”. Zdobycie owej mądrości pozwala spojrzeć szerzej na ludzkie doświadczenia i wyciągnąć właściwe wnioski. Dzięki temu można odnaleźć sens życia. Można też właściwie odczytać powołanie człowieka na ziemi. Człowiek mądry nie tylko sam potrafi podejmować właściwe decyzje w życiu, ale też może dopomóc innym. Ma on zdolność właściwego spojrzenia na świat.

Szacunek dla ludzi starszych wynika z Bożego przykazania: „Czcij swego ojca i swoją matkę, jak ci nakazał Pan, Bóg twój, abyś długo żył i aby ci się dobrze powodziło na ziemi, którą ci daje Pan, Bóg twój” (Pwt 5, 16). To przykazanie przekazane w tradycji zawartej w Księdze Powtórzonego Prawa niesie obietnicę. Jeśli człowiek będzie odnosił się z szacunkiem do swoich rodziców, wówczas i jemu będzie się dobrze wiodło w życiu. 
Przykazanie to znajduje się w szczegółowych pouczeniach, jakie stary Tobiasz skierował do swego syna: „Spraw mi piękny pogrzeb! Szanuj swoją matkę i nie zapominaj o niej przez wszystkie dni jej życia! Czyń to, co jej będzie miłe i nie zasmucaj jej duszy żadnym twoim uczynkiem! Przypomnij sobie, dziecko, na jak liczne niebezpieczeństwa była ona narażona $\mathrm{z}$ powodu ciebie, gdy cię w łonie swoim nosiła. A kiedy umrze, pochowaj ją obok mnie w jednym grobie!” (Tb 4, 3-4). Stary Tobiasz ma pełną świadomość bliskiej już swojej śmierci. Nie prosi wobec tego o nic innego dla siebie, jak tylko o godnie urządzony pogrzeb. Rozwijanie czci, jaką dzieci winni okazać rodzicom, jest podstawą wierności we wszystkich innych wymiarach życia ludzkiego. Relacje z innymi ludźmi rozpoczynają się od relacji z rodzicami. Jeśli człowiek potrafi okazać należyty szacunek swoim najbliższym, to będzie również umiał darzyć podobną czcią innych starszych ludzi. W starożytnym Izraelu cześć syna dla swej matki wdowy była czymś bardzo istotnym. Kobieta nie miała prawa dziedziczenia i posiadania jakiejkolwiek własności. Gdyby wdowa nie otrzymała wsparcia od swego syna, to nie miałaby środków do życia. Argumentem, o którym winien pamiętać Tobiasz, jest to, iż matka poniosła wiele trudów i narażała się na liczne niebezpieczeństwa w tym celu, aby on mógł przyjść na świat. W świecie starożytnym wiele kobiet umierało 
zarówno w stanie błogosławionym, jak też podczas porodu ${ }^{5}$.

Późne księgi Starego Testamentu jeszcze bardziej podkreślają konieczność troski, jaką dzieci winny okazać starszym, a zwłaszcza chorym rodzicom. „Synu, wspomagaj swego ojca w starości, nie zasmucaj go w jego życiu. A jeśliby nawet rozum stracił, miej wyrozumiałość, nie pogardzaj nim, choć jesteś w pełni sił. Miłosierdzie względem ojca nie pójdzie w zapomnienie, w miejsce grzechów zamieszka u ciebie" (Syr 3, 12-14). Warto zauważyć, że przykazanie czci okazywanej rodzicom w Biblii odnosi się przede wszystkim do dorosłych dzieci, które winny w należyty sposób otoczyć opieką starych już i schorowanych dawców ich życia.

\section{3.}

\section{Szczęśliwa starość}

Jeśli ktokolwiek myśli o starości, to zawsze pragnie, aby była ona szczęśliwa. Na kartach Pisma Świętego znajdziemy kilka tekstów pochwalających wiek sędziwy. Zarazem jednak teksty te wskazują na wartości, które liczą się wtedy szczególnie. Można wśród nich

5 Por. M. Wojciechowski, Księga Tobiasza, czyli Tobita. Wstęp, przekład $z$ oryginatu, komentarz (Nowy Komentarz Biblijny ST, XII), Częstochowa 2005, s. 83. 
wymienić: bliskość Boga, dobre zdrowie, grono dobrych przyjaciół, a także bogactwo zdobyte w ciągu życia, radość wynikającą z posiadania dzieci i wnuków. W Księdze Syracha czytamy: „[...] więcej wart biedny o zdrowiu i sile niż bogacz w ciele udręczonym [chorobą]. Zdrowie i siła lepsze są niż wszelkie złoto, a mocne ciało niż niezmierny majątek. Nie ma większego bogactwa nad zdrowie ciała, a dobrobyt nie przewyższa radości serca" (Syr 30, 14-16). Zawsze najważniejszą wartością dla człowieka było i nadal pozostaje zdrowie i dobra kondycja ciała. Drugą istotną wartością podkreślaną na kartach Biblii jest szacunek dla człowieka starszego. Szacunek ten nie wynika tylko z podeszłego wieku. Trzeba sobie na niego zasłużyć. Na takie traktowanie - z szacunkiem - w pełni zasłużył sobie stary Tobiasz. Całe życie przeżył w bliskości Boga, a kiedy umarł, pochowano go ze czcią (por. Tb 14, 2). Podobnie dożyła starości Judyta, otoczona szacunkiem z powodu dzieł, których za życia dokonała (por. Jdt 16, 21).

Dla ludzi obdarzanych szacunkiem i czcią zawsze wybierano jakieś szczególne miejsce pochówku i starano się wyraźnie zaznaczyć ich grób, aby na długie lata pozostawał w pamięci i cieszył się czcią potomnych. Abrahama pochowano w pieczarze Makpela przy dębach Mamre (Rdz 25, 9). Grota ta stała się miejscem pochówku wszystkich patriarchów. Także Józef Egipski zastrzegł, aby zabrać go z ziemi egipskiej 
i złożyć jego ciało tam, gdzie spoczywają przodkowie. Pochowano go zatem w Sychem.

Szczęśliwą starość mierzono również bogactwem zdobytym w ciągu życia. Dobrobyt pojmowano jako znak błogosławieństwa Bożego dla danego człowieka. Bogactwo mierzono ilością posiadanych trzód owiec, kóz, wielbłądów, par wołów (Hi 42, 12). Oznaką zamożności były też piękne szaty (Tb 10,10). W późniejszych czasach ważnym znakiem zamożności były winnice i obsiane zbożem pola ( $\operatorname{Prz} 3,10)$.

Oznaką szczęśliwej starości było nie tylko zdrowie i bogactwo. W Biblii ukazane jest także wielkie znaczenie umierania człowieka $\mathrm{w}$ sędziwym wieku, pośród dzieci i licznych przyjaciól, mimo że wiara w życie wieczne jest na kartach Starego Testamentu bardzo słabo udokumentowana. Nawet saduceusze żyjący w czasach Nowego Testamentu nie wierzyli w zmartwychwstanie umarłych. Odejście ludzi starszych rozumiano jako połączenie się ich ze swymi przodkami ${ }^{6}$. Śmierć przeżywano jako wydarzenie pełne tajemnicy. Wzruszające są opisy błogosławienia dzieci przez szczęśliwego ojca spoczywającego już na łożu śmierci.

6 Por. P. Ostański, Historiozbawcza wizja starości..., dz. cyt., s. 265. 


\section{4 .}

Przymioty człowieka w podeszłym wieku

\subsection{1.}

Mądrość

Człowiek, który zdobył doświadczenie życia, odznacza się przede wszystkim mądrością. W Starym Testamencie określano ją terminem hokmâ. Termin ten określa mądrość jako przymiot Boga i człowieka. Ks. Piotr Ostański ${ }^{7}$ zauważa, że termin ten występuje wielokrotnie na kartach Starego Testamentu. Różne znaczenia tego określenia można ograniczyć do zasadniczych trzech aspektów:

- mądrość w znaczeniu literackim. Przybiera formę lapidarnej wypowiedzi, sentencji, która w sposób doskonały i trafny opisuje napotkaną rzeczywistość.

- mądrość jako filozofia życia. Człowiek w podeszłym wieku posiada tak bogate doświadczenie, że potrafi doskonale znaleźć rozwiązanie każdej, nawet najtrudniejszej sytuacji. Taką mądrością odznaczał się król Salomon.

- mądrość w sensie jednostkowym. Tą kategorią posługiwała się późna literatura mądrościowa, w której można spotkać personifikację mądrości.

7 Por. tamże, s. 302-303. 
W naszym rozważaniu przede wszystkim warto skoncentrować się na drugim spośród wymienionych aspektów mądrości. W Księdze Syracha czytamy: „Jakże przystoi osąd siwym włosom, a starszym - umieć doradzać! Jakże starcom przystoi mądrość, a szanowanym rozeznanie i rada! Wieńcem starców jest wielkie doświadczenie, a chlubą ich bojaźń Pańska" (Syr 25, 4-6). Mądrość, którą może chlubić się człowiek w podeszłym wieku, jest wynikiem doświadczenia zdobywanego od młodości. Mądry starzec, który zdobył tę cnotę, zasługuje na ogromny szacunek. Będzie się on cieszył taką roztropnością, że ludzie młodsi będą chętnie przychodzić do niego po poradę. Szacunek zdobywany przez lata życia objawia się też odpowiednim odniesieniem do Boga, określonym przez Syracha jako bojaźń Boża, czyli taka postawa, która charakteryzuje się prawością i pobożnością ${ }^{8}$ Użyta w tekście metafora wieńca odnosi się do korony, czyli do władzy. Starszy człowiek ma władzę nad mądrością, którą zdobywał przez całe życie, i teraz może się nią chlubić.

Mądrość ta jest zwykle owocem doświadczenia. Człowiek, obserwując życie, może wiele się nauczyć. Z każdego doświadczenia może wyciągnąć wnioski na przyszłość. Doświadczenie to może obejmować obserwację przyrody. Obserwując otaczającą rzeczywistość,

8 Por. Biblia poznańska, przypis ad loc. 
z powtarzania się niektórych zjawisk można wywnioskować, jakie będą ich dalsze skutki. Po jakimś czasie można odkryć pewne prawidłowości dotyczące tego, co po czym zwykle następuje. Takie doświadczenie zwykle prowadzi autorów tekstów biblijnych do zachwytu nad Bożą mocą (Syr 42, 15-43). Biblijni bohaterzy obserwowali własne przeżycia. Potrafili z nich wysnuć bardziej ogólne wnioski, np. jak rozwiązywać problemy z bliźnimi. Cierpiący i opuszczony Hiob doskonale poznał, co znaczy samotność w cierpieniu (Hi 6, 14-30). Wiedział, jak bardzo wtedy potrzebni są przyjaciele. Niestety, on zawiódł się na nich, gdyż zamiast wsparcia doświadczył od nich jeszcze większej udręki (Hi 19, 1-3). Potrafił jednak zawierzyć Bogu nawet w takiej sytuacji, w której nie doznał wsparcia od nikogo, także od przyjaciół (Hi 19, 11-29)9.

Doświadczenie Boga prowadzi do najwyższej mądrości. W Starym Testamencie, a zwłaszcza w Księdze Przysłów, możemy znaleźć wiele sentencji opisujących relacje człowieka z Bogiem (na przykład: Prz 10, 22; $16,1.20 .33 ; 18,22 ; 19,14)$, jednak wyrażają one jedynie obserwacje człowieka i nie stanowią jeszcze Bożego Objawienia w tej materii ${ }^{10}$. Dopiero Chrystus przy-

9 Por. A. Niccacci, La casa della sapienza. Voce e volti della sapienza biblica, Torino 1994, s. 66.

10 Por. M. Filipiak, Księga Koheleta. Wstęp, przekład z oryginatu, komentarz, ekskursy (PŚST VIII, 2), Poznań 1980, s. 133n. 
niósł wiele treści ukazujących Bożą miłość do człowieka i Jego troskę o ludzkie zbawienie. On w pełni objawił, na czym polega ludzka relacja z Bogiem.

Mądrość nie zawsze zdobywa się wraz z wykształceniem. Nie jest ona też naturalnym wyposażeniem człowieka. Pragnąc ją zdobyć, trzeba wiele się natrudzić. Jest ona bowiem wynikiem wielorakich doświadczeń człowieka, który potrafi poddać głębokiej refleksji to, co przeżywa w życiu. Księga Mądrości podpowiada, że trzeba o mądrość prosić Boga (Mdr 9, 1-18) ${ }^{11}$.

\subsection{2.}

Przekazywanie tradycji, dzielenie się mądrością

Ważnym zadaniem ludzi doświadczonych przez życie jest troska o przekaz tradycji. Mądrość nie jest możliwa do zdobycia przez jednego człowieka. Jest ona sumą doświadczeń wielu pokoleń ludzi, którzy doświadczywszy mądrości, potrafią przekazać ją potomnym. Prawdę o przekazywaniu tradycji ukazuje dyskusja Hioba z przyjaciółmi. Między innymi Bildad w swojej mowie wzywa Hioba, aby sięgnął do doświadczenia minionych pokoleń (Hi 8, 8). Zauważa on, że życie pojedynczego człowieka jest zbyt krótkie, aby nauczyć się mądrości. W trudnej sytuacji Hiob winien sięgnąć do doświadczeń minionych pokoleń. Jednak okazuje się,

11 Por. A. Niccacci, La casa della sapienza..., dz. cyt., s. 155-156. 
że doświadczenie cierpiącego Hioba jest tak trudne, że nie można znaleźć nań odpowiedzi u starożytnych mędrców, nawet zsumowanie tego doświadczenia jest jeszcze zbyt małe. Odpowiedź na pytania o sens cierpienia przyniesie dopiero męka Chrystusowa. Objawienie Nowego Testamentu jest niezwykle ważne w tej materii. Niestety zwykle wiek podeszły łączy się z trudnym doświadczeniem cierpienia. I wcale nie musi to być kara Boża za grzechy, popełnione choćby nieświadomie, jak to próbowali wmówić przyjaciele Hiobowi. Cierpienie Chrystusa przyjęte całkowicie dobrowolnie ukazuje wartość ekspiacji, jakiej On dokonał. Ciężar Jego męki jest miarą miłości Boga do człowieka. Jednak jakże ważne jest zdanie zapisane w Liście do Kolosan: „Teraz raduję się w cierpieniach za was i ze swej strony w moim ciele dopełniam braki udręk Chrystusa dla dobra Jego Ciała, którym jest Kościół" (Kol 1, 24). Trzeba zaznaczyć, że Chrystusowa męka jest zupełnie wystarczającym zadośćuczynieniem za ludzkie grzechy, jednak Boża miłość pozwala człowiekowi cierpiącemu włączyć się w to dzieło. Komentatorzy zawężają rozumienie tekstu i widzą w nim włączenie w mękę Chrystusa wszystkich trudów i ucisków Apostoła Narodów dla szerzenia Ewangelii celem zaniesienia Chrystusowego orędzia aż na krańce ziemi ${ }^{12}$.

12 Por. B. Adamczewski, List do Filemona. List do Kolosan. Wstęp, przekład z oryginału, komentarz (NKB NT XII), Częstochowa 
Troska o przekazywanie tradycji nie dotyczy tylko odszukania sensu cierpienia. W języku bardziej współczesnym zamyka się ona w przysłowiu: „historia jest matką życia”. Księga Powtórzonego Prawa $(32,7)$ ukazuje, że starożytna tradycja przekazywana przez ojców odnosi się do działania Bożego, a także do mądrości rozumianej jako sztuka życia. Ludzie starsi, przekazując dzieciom i wnukom tę umiejętność, stają się zwornikami przeszłości z teraźniejszością i przyszłością.

\subsection{3.}

Mądrość objawiająca się zjednoczeniem z Bogiem

Biblia ukazuje, na czym polega prawdziwa mądrość życia. Skoro dawcą wszelkich darów jest Bóg, to mądrość życia polega na stałym zjednoczeniu z Nim. Zadaniem człowieka jest trwanie przy Bogu od samej młodości. Księga Syracha stwierdza: „Dziecko, od młodości troszcz się o karność, a do siwizny znajdziesz mądrość" (Syr 6, 18). Mądrości nie można zdobyć w jednym momencie. Trzeba się o nią troszczyć przez całe życie. Właściwym momentem, by rozpocząć formowanie siebie, jest wejście w wiek młodości. Kilka rozdziałów dalej Syrach podaje już bardzo konkretne wskazówki: „Trwaj w przymierzu

2006, s. 227-228. 
twoim i bądź mu oddany, a wypełniając je zestarzej się" (Syr 11, 20) ${ }^{13}$. Septuaginta używa tu terminu diathēkē, który dosłownie znaczy testament, ale w tłumaczeniu greckim Pisma Świętego jest odnoszony do przymierza z Bogiem. Trwanie w przymierzu z Bogiem oznacza postawę człowieka, który jest wierny Bogu i stale żyje w zjednoczeniu z Nim.

\subsection{4.}

Mądrość objawiająca się rozliczeniem się przed Bogiem z grzechów młodości

Nieco inaczej przedstawia się perspektywa życia w okresie młodości, a inaczej w wieku dojrzałym. W wieku starszym często powraca się myślami do lat minionych. Wiele dobrych czynów dokonanych w ciągu życia napawa radością człowieka będącego u kresu swych dni. Niestety wielką zmorą dla człowieka starszego są błędy młodości. Wspominając je, starszy człowiek winien zwrócić się do Boga i wypraszać miłosierdzie dla siebie i przebaczenie tych wszystkich grzechów. Psalm 25 jest przykładem takiej modlitwy. Warto zwrócić uwagę między innymi na dwa wersety tego psalmu: „Nie wspominaj grzechów mej młodości ani moich przewin, ale o mnie pamiętaj w Twojej

13 Tłumaczenie za: P. Ostański, Historiozbawcza wizja starości..., dz. cyt., s. 322 . 
łaskawości ze względu na dobroć Twą, Panie! (w. 7), oraz: „Wejrzyj na udrękę moją i na boleść i odpuść mi wszystkie grzechy" (w. 18). Psalm ten jest modlitwą błagalną skierowaną do Boga przez człowieka w podeszłym wieku. Autor biblijny przypisał go Dawidowi jako modlitwę błagalną starego już i znękanego życiem króla. Egzegeci widzą jednak zależność tego tekstu od mędrców i określają czas jego powstania na zbliżony do okresu niewoli babilońskiej ${ }^{14}$.

\section{5.}

Negatywne aspekty starości

Pragnąc właściwie odczytać biblijne spojrzenie na problem starości, trzeba wziąć pod uwagę czas powstania danego fragmentu Biblii. Życie wieczne rozumiane jako życie człowieka po śmierci pojawia się w Bożym Objawieniu bardzo późno. Dopiero w II wieku przed Chrystusem na kartach Biblii można znaleźć teksty jasno mówiące o życiu po śmierci. Wtedy znacznie mniejszą rolę odgrywa długie życie na ziemi. Jednak nie od razu jest to wiara powszechna. Jeszcze w czasach Chrystusa stronnictwo saduceuszów

14 Por. W. Borowski, Psalmy. Komentarz biblijno-ascetyczny, Kraków 1983, s. 118. Ten autor określa czas powstania na okres przed niewolą babilońską. Ostański przesuwa czas powstania na okres po niewoli babilońskiej. Por. P. Ostański, Historiozbawcza wizja starości..., dz. cyt., s. 325. 
nie dopuszczało takiej wiary. Jednak nauczanie Jezusa nie pozostawia cienia wątpliwości odnośnie do istnienia życia wiecznego.

Perspektywa życia wiecznego jest ogromnie ważna dla właściwego podejścia do kwestii starzenia się i właściwego przeżywania starości.

Autorzy ksiąg biblijnych są dobrymi obserwatorami życia. Bardzo realnie widzą i opisują problem wieku starszego. Teksty biblijne opisujące proces starzenia się są bardzo realistyczne. Starzejący się Izaak stracił wzrok (por. Rdz 27, 1-40). Miał trudności w rozpoznaniu swoich synów, przez co udzielił błogosławieństwa Jakubowi, a Ezawowi przepowiedział bardzo trudne życie. Podobnie kapłan Heli bardzo cierpiał z powodu utraty wzroku i coraz mniejszej sprawności fizycznej (1 Sm 3, 2). Zamieszkał przy nim Samuel, aby usłużyć mu w razie potrzeby i ulżyć w zmaganiu się z trudnościami wynikającymi z podeszłego wieku, choroby i niesprawności fizycznej. Król Dawid na starość nie mógł się rozgrzać, dlatego przyprowadzono do niego dziewicę, Szunamitkę Abiszag, aby usługiwała mu w tych trudnych chwilach gasnącego życia (1 Krl 1, 1-4). Krytycznie oceniany jest też stary Salomon. Chcąc pokazać swój przepych, rozbudował harem do granic absurdu. Miał siedemset żon i trzysta nałożnic. Autor natchniony stwierdza, że te żony uwiodły go i zaczął oddawać cześć innym bogom. Dla bożków swoich żon zbudował ołtarze na wzgórzu 
leżącym na południowy wschód od wzgórza świątynnego. Obecnie wzgórze to nazywa się Górą Zgorszenia (1 Krl 11, 1-8).

Jeszcze bardziej pesymistycznie wypowiada się jeden ze sług Dawida, Barzillaj z Gileadu. Całe życie pełnił wierną służbę u Dawida. Dlatego król ten chciał go na starość wziąć do Jerozolimy i otoczyć opieką. Sługa ów bardzo realnie popatrzył na propozycję i, odmawiając królowi, stwierdził: „Liczę obecnie osiemdziesiąt lat. Czy potrafię rozróżnić między tym, co dobre, a tym, co liche? Czy sługa twój potrafi zasmakować w tym, co zje lub wypije? Czy potrafi wsłuchiwać się w głos śpiewaków i śpiewaczek?" (2 Sm 19, 36). Sługa ten ma pełną świadomość, że w podeszłym wieku obniża się znacznie sprawność rozeznania, podejmowania decyzji. Człowiek traci wtedy smak. Słuch nie jest już tak sprawny jak wcześniej ${ }^{15}$.

Jeśli przyjąć, że Psalm 90 jest autorstwa Dawida, to być może własne doświadczenie króla albo też przytoczona powyżej rozmowa z sługą Barzillajem skłoniła go do takiej refleksji: „Czas naszych dni - to lat siedemdziesiąt lub, gdy jesteśmy mocni, osiemdziesiąt; a większość z nich - to trud i marność, bo szybko mijają, my zaś odlatujemy" (Ps 90, 10). Psalm ten podaje dwie przyczyny krótkiego życia człowieka

15 Por. A. Tronina, Biblia o ludziach starszych, „Vox Patrum” 31 (2011) t. 56, s. 232-233. 
i jego trudnej starości. Pierwszą jest grzech człowieka, a drugą Boży gniew, który jest odpowiedzią na ludzką grzeszność. W tekście Psalmu odpowiedź jest bardzo jasna: zapłatą za grzech człowieka jest śmierć ${ }^{16}$. Jednak czy chodzi tutaj tylko o śmierć ciała? Oczywiście w tekstach Starego Testamentu na pierwsze miejsce wysuwa się takie właśnie rozumienie. Grzesznik ponosi karę i musi umrzeć. Najczęściej rozumie się tę śmierć jako śmierć fizyczną. Jednak już w Starym Testamencie mocno stawiano pytanie, czy rzeczywiście choroba, cierpienie i w końcu śmierć są bezpośrednim skutkiem grzechu? Księga Hioba ten temat podejmuje i daje zaskakującą odpowiedź: nie zawsze cierpienie i choroba są skutkiem grzechu. Sprawiedliwy Hiob stracił majątek, dzieci, w końcu został doświadczony przez Boga trądem, i nawet $w$ tak strasznym położeniu nie złorzeczył Bogu, ale powiedział: „Dobro przyjęliśmy z ręki Boga. Czemu zła przyjąć nie możemy?” (Hi 2, 10). $\mathrm{W}$ tej księdze nie znajdziemy jeszcze pełnej odpowiedzi na nurtujące nas pytania. Trzeba sięgnąć do Nowego Testamentu. Pełnia Objawienia dokonała się dopiero w Jezusie Chrystusie.

16 Por. S. Łach, Księga Psalmów..., dz. cyt., s. 399. 


\section{2. \\ Nowy Testament o starości}

Również w Nowym Testamencie można znaleźć tak wiele ciekawych tekstów na temat starości, że w krótkim artykule można jedynie dotknąć niektórych z nich. Już w Ewangelii Dzieciństwa u św. Łukasza można znaleźć bardzo piękne wzorce ludzi starszych, żyjących pięknie, otoczonych powszechnym szacunkiem. Niewątpliwie do takich ludzi należą Zachariasz i Elżbieta - rodzice Jana Chrzciciela. Podobnie piękną opinią cieszyli się starzec Symeon i prorokini Anna. Symeon określony jest jako mąż sprawiedliwy i pobożny, napełniony Bożym Duchem. Jako przedstawiciel ludu Izraela zamykający czasy Starego Testamentu doczekał się spotkania z przychodzącym Mesjaszem, którego napotkał w świątyni w postaci czterdziestodniowego Niemowlęcia przyniesionego do świątyni przez Rodziców.

Można odnaleźć też teksty podsumowujące działalność Apostoła Narodów - św. Pawła. Do swojego ucznia Tymoteusza św. Paweł napisał takie słowa: „W dobrych zawodach wystąpiłem, bieg ukończyłem, wiary ustrzegłem" (2 Tm 4, 7). Słowa Apostoła komentatorzy interpretują na dwa sposoby. Pierwszy z nich skłania się do rozumienia słów św. Pawła jako podsumowania życia. Od spotkania Chrystusa pod Damaszkiem całkowicie poświęcił się głoszeniu 
Ewangelii. Swoją misję wiernie wypełnił. Już ją kończy i nadchodzi śmierć. Odtąd nie będzie się już musiał więcej trudzić i zmagać z przeciwnościami. Teraz już tylko oczekuje od swego Pana wiecznej nagrody, o czym mówią dalsze słowa listu. Druga interpretacja kładzie nacisk na sportowy wymiar słów. Apostoł okazał się dobrym i wiernym zawodnikiem. Dzielnie walczył przez całe życie i wreszcie dobiegł do mety.

Kościół pierwszego wieku wielką troską otaczał ludzi starszych. Powołał specjalną instytucję wdów, których zadaniem było trwanie na modlitwie i praca charytatywna na rzecz wspólnoty. Św. Paweł, kierując list do Tytusa, wylicza cechy człowieka w podeszłym wieku: „Starcy winni być ludźmi trzeźwymi, statecznymi, roztropnymi, odznaczającymi się zdrową wiarą, miłością, cierpliwością" (Tt 2,2).

\section{1.}

Śmierć w nauczaniu Jezusa i późnych tekstach Nowego Testamentu

Intrygująca jest przypowieść o miłosiernym ojcu (Łk 15, 11-32). W tekście tym aż dwukrotnie jest powiedziane, że syn marnotrawny umarł i ponownie powrócił do życia. Pierwszy raz słowa te są skierowane do sług, którym ojciec poleca przygotowanie uczty: „Przyprowadźcie utuczone cielę i zabijcie: 
będziemy ucztować i weselić się, ponieważ ten syn mój był umarły, a znów ożył; zaginął a odnalazł się" (Łk 15, 23-24). Drugi raz te słowa ojciec powtórzył do starszego syna, który nie chciał wejść na ucztę (Łk 15, 32). Wynika z tego, że dla Jezusa śmiercią jest grzech człowieka. Pełniejszy obraz myślenia Jezusa można uzyskać zestawiając te wypowiedzi z tekstem zaczerpniętym $z$ Ewangelii św. Jana. Kiedy Łazarz umarł, Jezus powiedział do swoich uczniów: „Łazarz, przyjaciel nasz, zasnął, ale idę, aby go obudzić" (J 11,11). Dla Jezusa śmierć fizyczna jest snem, a grzech jest śmiercią duchową.

Podobną myśl możemy odnaleźć w słowach Jezusa: „Nie bójcie się tych, którzy zabijają ciało, a potem już nic więcej uczynić nie mogą. Pokażę wam, kogo się macie obawiać: bójcie się Tego, który po zabiciu ma moc wtrącić do piekła” (Łk 12,4-5). Tekst ten nie odnosi się do starości ani też do śmierci, która wynika z długiego życia i nadejścia jego kresu. Tekst ten skierowany został do uczniów Chrystusa, których Jezus pragnie posłać do głoszenia Ewangelii. W tej posłudze niejednokrotnie mogą napotkać prześladowania, łącznie z zabiciem ich. Jednak tej śmierci nie trzeba się lękać w perspektywie życia wiecznego. Prawdziwie obawiać się trzeba śmierci wiecznej, wynikającej z grzesznego życia. Chrześcijanin nie ma potrzeby obawiać się prześladowców. Prawdziwie lękać się trzeba Tego, który „po zabiciu ma moc posłać do 
Gehenny"17. Tak brzmi dosłowne tłumaczenie wersetu 12, 5. Tym, który ma taką moc, jest sam Bóg. Możemy tu odnaleźć nawiązanie do Księgi Przysłów, w której czytamy, że podstawą mądrości jest Bojaźń Boża (por. Prz 1, 7). Ta bojaźń Boża polega na dobrze rozumianym lęku przed grzechem. Człowiek winien się lękać obrażania Boga grzechem. W kontekście naszych rozważań można stwierdzić, że człowiek dojrzały (w starszym wieku) winien posiadać taką mądrość, polegającą na bojaźni Bożej.

Dla odróżnienia od śmierci fizycznej Apokalipsa św. Jana posługuje się terminem „śmierć druga”. Określenie to występuje w Apokalipsie czterokrotnie. Dwa wystąpienia odnoszą się do zwycięzców, ludzi prawych. „Zwycięzcy śmierć druga na pewno nie wyrządzi szkody" (Ap 2, 11). Wyrażenie to można napotkać w literaturze żydowskiej (Targum Jerozolimski do Pwt 33, 6). W Apokalipsie oznacza wieczne potępienie. Wyrażenie to zostało zawarte $\mathrm{w}$ zakończeniu Listu Apokalipsy do Kościoła w Smyrnie. Był to ubogi Kościół w bogatym mieście. Jego ubóstwo zostało świadomie wybrane przez chrześcijan, który nie chcieli brać udziału w kultach pogańskich. Każdy rzemieślnik należał w tym mieście do cechu

17 Por. F. Mickiewicz, Ewangelia wedtug św. Łukasza, rozdziały 12-24. Wstę, przekład $z$ oryginatu, komentarz (NKB NT III, 2), Częstochowa 2012, s. 31. 
zrzeszającego mistrzów z tej samej branży. Cechy miały bóstwa opiekuńcze. Ku ich czci organizowały różne uroczystości. Włączały się też w kult imperialny skierowany ku czci boskiego cesarza. Ten właśnie kult był główną przyczyną prześladowań chrześcijan. Autor kieruje słowa otuchy do męczenników: „Bądź wierny, aż do śmierci a dam Ci wieniec życia [...] Zwycięzcy śmierć druga na pewno nie wyrządzi szkody"(Ap 2, 10-11) ${ }^{18}$.

Drugi raz interesujący zwrot występuje przy końcu tej Księgi: „Błogosławiony i święty, kto ma udział w pierwszym zmartwychwstaniu: nad tymi nie ma władzy śmierć druga" (Ap 20, 6). Błogosławieństwo skierowane jest do zwycięzców, którzy wytrwali przy Chrystusie. Po zmartwychwstaniu do wiecznego życia w Chrystusie nie ma już zagrożenia skutkującego potępieniem.

Kolejne dwa użycia analizowanego określenia występują w negatywnym znaczeniu. „To jest śmierć druga - jezioro ognia. Jeśli się ktoś nie znalazł zapisany w księdze życia, został wrzucony do jeziora ognia" (Ap 20, 14-15). Ostatnia wypowiedź nie pozostawia wątpliwości: „A dla tchórzów, niewiernych, obmierzłych, zabójców, rozpustników, guślarzy, bałwochwalców i wszelakich kłamców udział w jeziorze gorejącym

18 Por. A. Jankowski, Apokalipsa św. Jana. Wstęp, przekład z oryginału, komentarz (PŚNT XII), Poznań 1959, s. 150. 
ogniem i siarką. To jest śmierć druga" (Ap 21, 8). Ci, którzy odrzucili Chrystusa, doświadczą drugiej śmierci. Będzie ona całkowitym unicestwieniem ${ }^{19}$.

\section{Podsumowanie}

Wiek podeszły sprawia, że człowiek zaczyna zastanawiać się nad wieloma sprawami, które do tej pory nie zajmowały go aż tak bardzo. Przyczyniają się do tego zapewne różne trudne doświadczenia. Przede wszystkim obniżona sprawność fizyczna, słabszy wzrok, przytępiony słuch, a często doświadczenie choroby. Wraz z odchodzeniem z tego świata rówieśników pojawia się też nieunikniona refleksja nad kwestią śmierci. Do tego dochodzą egzystencjalne pytania o dalsze życie, zwłaszcza w kontekście braku sił do pracy i odejścia na emeryturę czy rentę zdrowotną. Jeszcze bardziej bolesna jest utrata pracy i niemożność znalezienia dla siebie jakiegoś zajęcia. Przychodzi wtedy utrata sensu życia. Człowiek zastanawia się również nad kwestią śmierci: i co dalej...? Czy istnieje życie wieczne?

Niniejszy artykuł ma na uwadze trudne doświadczenie współczesnego człowieka i próbuje znaleźć

19 Por. F. Rienecker, G. Maier, Leksykon biblijny, Warszawa 2001, s. 792. 
odpowiedź na pytania nasuwające się podczas lektury Biblii. Okazuje się jednak, że problem jest bardzo trudny. Przede wszystkim w Biblii widać wyraźny rozwój Objawienia w tym względzie. W czasach prehistorycznych sądzono, że długowieczność jest oznaką Bożego błogosławieństwa. Również cieszenie się dobrym zdrowiem, bogactwem i dostatnim życiem przez wiele wieków uznawano za znak Bożej odpłaty za dobre życie człowieka. Stary Testament w ogóle nie potrafił sobie poradzić $\mathrm{z}$ sensem cierpienia. Autorzy biblijni dostrzegają problem, ale nie potrafią sobie z nim poradzić. Do czasów niewoli babilońskiej sądzono, że cierpienie jest karą Bożą. Zwłaszcza Księga Hioba próbuje podejmować zagadnienie cierpienia i nie do końca potrafi dać jakieś rozwiązanie. Wyraźnie ukazuje, że niekoniecznie to musi być kara Boża.

Równie ciekawe jest podejście do śmierci i życia wiecznego. Stary Testament mówi tylko o Szeolu, ale nie daje odpowiedzi na pytanie o życie człowieka po śmierci. Ostatnie księgi Starego Testamentu delikatnie podejmują ten temat (2 Mch 12, 38-43), lecz o zmartwychwstaniu, poza tym tekstem, nic nie mówią. Dopiero Chrystus, dając pełnię Objawienia, ukazał wartość cierpienia poprzez swą zbawczą mękę. Objawił też prawdę o zmartwychwstaniu ciał i życiu wiecznym. Nauczał, że śmierć jest tylko snem - chwilą przejścia do innego, wiecznego, życia. 
Teksty biblijne ukazują, że starość jawi się jako zadanie, które trzeba dobrze odrobić. To zadanie człowiek odrabia przez całe życie. Mądrość zdobywa się wraz z doświadczeniem. Zadaniem jest zdobywanie doświadczenia i mądrości życia, ale jawi się też drugie, o wiele trudniejsze zadanie - jest nim ciągła praca wewnętrzna polegająca na odkrywaniu swego powołania. Zasadniczym powołaniem człowieka jest zjednoczenie z Bogiem na całą wieczność. Choroba i cierpienie mogą nabrać nowego wymiaru poprzez zjednoczenie z Chrystusową męką. Tym nowym wymiarem jest włączenie się w dzieło zbawienia człowieka i świata poprzez własne cierpienie. Cierpienie ma jednak jeszcze jedno zadanie. Człowiek chory traci chęć życia na ziemi i zaczyna myśleć o życiu wiecznym. 


\section{Summary}

\section{Old age in the Bible}

The article Old age in the Bible is a synthetic attempt to answer the modern man's existential questions asked initially. Is old age always connected with hardship, suffering and keeping death in mind? Does it always have to be a negative experience? What does the Bible say about old age? How does it view elderly people? The answer is based on the holy books.

Long life was regarded as a sign of God's blessing in the prehistoric times. The same was also believed about good health, wealth and any kind of abundance as rewards for living a good life. The Old Testament could not handle the sense of suffering at all. Biblical writers noticed the existence of pain but were not able to see any point in it. Until the Babylonian Captivity suffering had been regarded as God's punishment. Especially The Book of Job attempted to deal with misery and distress, yet it did not provide any distinct solution. However, it shows clearly that it is not necessarily God's punishment.

The attitude towards the death and the eternal life is equally interesting. The Old Testament mentions only Sheol but does not describe life after death. The last Old Testament books take this topic up (2 Mch 12, 3843) but they do not refer to resurrection. It was only 
Jesus Christ who has revealed in the fullest and who has shown the value of suffering in his death. He is also the One who reveals the truth about the resurrection of the body and about the eternal life. In his teaching the death is only a dream, a moment when we pass to another, eternal life. In the Apocalypse we may also find the expression "another death" which is the end of the evil and those who denied God and His rules from their lives.

Keywords: old age, respect, wisdom, suffering, death

\section{Bibliografia}

Adamczewski A., List do Filemona. List do Kolosan. Wstęp, przekład $z$ oryginału, komentarz (NKB NT XII), Częstochowa 2006. Borowski W., Psalmy. Komentarz biblijno-ascetyczny, Kraków 1983.

Chrostowski W., Czy Adam i Ewa mieli się nie starzeć i nie umierać? Egzegetyczny przyczynek do nauczania o nieśmiertelności pierwszych ludzi, [w:] „Verbum caro factum est”. Ksiega pamiątkowa dla Księdza Profesora Tomasza Jelonka w 70. rocznicę urodzin, red. R. Bogacz, W. Chrostowski, Warszawa 2007.

Encyclopaedia of religion and ethics, ed. by J. Hastinfs, vol. 9, New York 1960, s. 478-479.

Filipiak M., Księga Koheleta. Wstęp, przekład z oryginału, komentarz, ekskursy (PŚST VIII, 2), Poznań 1980. 
Jankowski A., Apokalipsa św. Jana. Wstęp, przekład z oryginału, komentarz (PŚNT XII), Poznań 1959.

Łach S., Księga Psalmów. Wstęp - przekład z oryginału, komentarz-ekskursy, Poznań 1990.

Mickiewicz F., Ewangelia wedtug św. Łukasza, rozdziały 12-24. Wstęp, przekład z oryginału, komentarz (NKB NT III, 2), Częstochowa 2012.

Niccacci A., La casa della sapienza. Voce e volti della sapienza biblica, Torino 1994.

Ostański P., Historiozbawcza wizja starości w Piśmie Świętym. Studium egzegetyczno-teologiczne, Poznań 2007.

Rienecker F., Maier G., Leksykon biblijny, Warszawa 2001.

Tronina A., Biblia o ludziach starszych, „Vox Patrum” 31 (2011) t. 56 , s. $232-233$.

Wojciechowski M., Księga Tobiasza, czyli Tobita. Wstęp, przekład z oryginału, komentarz (NKB ST XII), Częstochowa 2005. 